Article

\title{
Survival of Quercus alba (White Oak) Advance Reproduction in Small Group and Single Tree Openings
}

\author{
Martin A. Spetich \\ United States Forest Service, Southern Research Station, Arkansas Forestry Sciences Laboratory, P.O. Box 1270, \\ Hot Springs, AR 71902, USA; marty.spetich@usda.gov; Tel.: +1-501-623-1180 (ext. 105)
}

Received: 15 July 2020; Accepted: 11 August 2020; Published: 15 August 2020

\begin{abstract}
Survival probabilities of white oak (Quercus alba) in small circular group and single tree openings ranging in size from 0.001 to 0.175 ha twelve years after opening creation are presented. At the beginning of the study, 3948 advance reproduction white oak trees were measured and tagged to determine survival of each tagged seedling at the end of the study. Logistic regression indicated that variables important in predicting advance reproduction survival included initial seedling basal diameter, aspect, slope, canopy opening size, opening border tree height and treatment for control of understory competition. Survival probability ranged from $10 \%$ to $90 \%$ depending on the combination of and disposition of variables. For these small openings, the greatest probability of survival of advance reproduction resulted when advance reproduction initial basal diameters were $\geq 1 \mathrm{~cm}$, when the height of trees bordering the openings were relatively short, with understory chemical competition control, in the largest canopy openings, on $6 \%$ slopes, and on southwest and northwest aspects. These criteria can help managers select sites and treatment options for group opening creation that provide optimal conditions for advance reproduction survival.
\end{abstract}

Keywords: white oak; group opening; survival; advance regeneration; reproduction

\section{Introduction}

Group selection is a regeneration method in which trees are harvested in small groups which typically range in size from 0.08 to 0.20 ha [1] but can sometimes be as large as 0.80 ha. Group selection is a useful silvicultural tool when planning management of forests in visually sensitive areas and where uneven-aged forest management is desired. This method minimizes visual impacts by distributing small canopy openings across a forest. Another aim in using group selection is to maintain advance regeneration of tree species that are mid-tolerant to shade and those that are shade-intolerant. Normally the diameter of a circular canopy opening created through group selection is equal to at least one-tree-height of the trees bordering the opening [2] with a maximum opening size of twice the height of mature trees [3]. Maximizing survival of advance oak reproduction in small openings, where border tree height is greater than the diameter of the canopy opening, such as those produced from removal of single trees, is poorly understood, especially for white oak (Quercus alba). Note that throughout this manuscript the term reproduction refers to plants and regeneration refers to process.

Oaks are keystone species across forests of the Eastern United States [4]. However, reproduction of oaks has been declining across the area since at least the 1970s [5]. White oak is important to wildlife, to forest aesthetics and to wood-oriented industries making products ranging from cooperage to furniture and cabinetry. Oak decline has impacted millions of acres of forest across the Eastern United States and is expected to be a significant problem in the future [6,7] making it imperative to regenerate species resistant to oak decline to help maintain oak in future forests. More resistant to 
oak decline than most other oak species [6,8], white oak also has shown increased growth efficiency in a $\mathrm{CO}_{2}$-enriched atmosphere, an increasingly important attribute [9]. Additionally, white oak is considered intermediate in shade tolerance lending itself well to the group opening environment.

Group selection can be useful in regenerating intermediate shade-tolerant species [10]. Fan, et al. [11] found that group selection was a useful method for regenerating white oak on sites with high oak regeneration potential such as those found in the Ozark Highlands. Jenkins and Parker [12] found that oak species were more important in group openings on dry-mesic slopes than mesic slopes. Group selection was also effective in mitigating oak decline for up to 50 years in a modeling study examining harvesting alternatives on oak decline [13]. However, attributes that maximize survival of white oak using this method have not been fully examined.

The overarching goal in this study was to determine how to maximize survival of white oak advance reproduction in small group openings. The objectives of this analysis are to (1) evaluate the effect of competition control on survival of white oak advance reproduction in group openings, (2) evaluate the relationship of border tree height to white oak advance reproduction survival including canopy openings smaller in diameter than average border tree height, and (3) determine the size of advance white oak reproduction necessary to maximize survival in small group openings.

\section{Materials and Methods}

\subsection{Site Description}

This small group opening study was established in the Ozark-St. Francis National Forest in the Boston Mountains of Arkansas. This area encompasses the southernmost lobe of the central hardwood region [14] (p. 108) and the Boston Mountain Section (M222A) of the Hot Continental Division (220) of Bailey's ecoregions [15]. Part of the Ozark Highland Physiographic Province, the Boston Mountains are part of an uplifted peneplain. Mountaintops are relatively level to gently rolling, while mountainsides are an alternating series of steep slopes and gently sloping benches. Study plots were established in stands 70 to 90 years old that were predominantly sawtimber size with basal areas of at least $16 \mathrm{~m}^{2} / \mathrm{ha}$.

\subsection{Study Establishment, Measurements and Treatments}

In 1990, six upland hardwood forest stands were identified and eighteen future openings were located within each stand. These openings were established in six sizes with radii of $5.68 \mathrm{~m}, 8.03 \mathrm{~m}$, $11.35 \mathrm{~m}, 16.05 \mathrm{~m}, 21.23 \mathrm{~m}$ and $25.5 \mathrm{~m}$ as measured to the trunks of bordering trees. This method of measuring to the bordering tree trunks helped to simplify logistics of establishing the openings but does not define the canopy opening area.

Within each future opening, permanent reproduction measurement plots were established. Reproduction measurement plots were not restricted by area but by meeting seedling measurement criteria where the goal was to measure two seedlings in each 2.54-cm height class. To increase field efficiency, technicians began by measuring all white oak reproduction within a standard radius from plot center and continued beyond the starting radius until up to two seedlings for each 2.54-cm height class were located (with distance and azimuth from plot center recorded for every stem). Starting radii increased with opening size ranging from $1.13 \mathrm{~m}$ in the smallest openings to $2.44 \mathrm{~m}$ in the largest. The smallest two future openings had five reproduction plots, while larger future openings had nine. One reproduction measurement plot was placed at the center of the opening. The other plots were placed along the four cardinal directions. In openings with nine plots, the additional four plots were placed midway between the opening center plot and the outer plots.

In late 1990 (July through November), individual stems of advance reproduction less than $4 \mathrm{~cm}$ diameter at breast height (d.b.h.) in the reproduction plots were measured, and each measured stem was identified by a unique identification number on a metal tag so it could be tracked throughout the study. Measurements of advance reproduction included basal diameter to the nearest $0.254 \mathrm{~cm}$ (measured at $2.54 \mathrm{~cm}$ above ground level on the uphill side of each stem). 
Three understory treatments were applied in early 1991. The treatments were:

- $\quad \mathrm{U} 1$, no control of competing reproduction;

- $\quad \mathrm{U} 2$, mechanical control of all competing woody stems greater than $30.5 \mathrm{~cm}$ tall and less than or equal to $14 \mathrm{~cm}$ d.b.h. (cut stems);

- $\quad \mathrm{U} 3$, chemical control of all competing woody stems greater than $30.5 \mathrm{~cm}$ tall and less than or equal to $14 \mathrm{~cm}$ d.b.h. (cut stems sprayed with an herbicide).

Competing vegetation to be controlled consisted of all woody vegetation excluding white oak, northern red oak (Quercus rubra L.), black oak (Quercus velutina Lam.), black cherry (Prunus serotina Ehrh.), white ash (Fraxinus americana L.), post oak (Qurecus stellata Wangenh.), hickory (Carya Nutt.), and black walnut (Juglans nigra L.).

In 1992, group openings were created by harvesting all trees greater than or equal to $14 \mathrm{~cm}$ d.b.h. within the border tree area of the previously established future openings. The study is a split plot experimental design with 6 replicates (stands). There were 108 openings in total ( 6 opening sizes $\times 3$ treatments $=18$ openings per stand, and 18 openings $\times 6$ stands $=108$ ). After the harvest, the distance to the drip line of the bordering trees was measured. This defined the canopy opening area which ranged from 0.001 to 0.175 ha that was used in analysis of reproduction response to canopy opening size.

The ranges of initial seedling basal diameter (i.e., the diameter measured in 1990), aspect, slope, canopy opening diameter and border tree height were 0.254 to $5.6 \mathrm{~cm}, 2$ to 360 degrees, $6 \%$ to $30 \%, 5$ to $48 \mathrm{~m}$, and 17.6 to $30.4 \mathrm{~m}$, respectively. All illustrations in this manuscript are within these ranges.

\subsection{Data Analysis and Modeling}

White oak advance reproduction survival was examined in relation to initial seedling basal diameter, aspect, slope, canopy opening size, border tree height, and understory treatment. Logistic regression was used to estimate survival probabilities of the advance reproduction 14 years after initial measurement (13 years after understory treatment and 12 years after harvest/group opening creation). We used the model building approach recommended in Hosmer and Lemeshow's [16] (p. 82) text on applied logistic regression. Logistic regression has been used in studies to predict oak reproduction [17], to estimate the contribution of planted trees to future stocking [18], to model regeneration of oak stands [19], and to determine the competitive capacity of planted oaks [4].

Independent variables included initial basal seedling diameter, aspect, slope, diameter of canopy openings, border tree height, and three levels of competition control. The dependent variable is survival of advance reproduction of white oak that was present during the initial 1990 inventory.

In logistic regression, the observed value of the dependent variable is binary ( 0 or 1$)$; however, the resulting probability estimates are continuous and restricted to the interval 0 to 1 . To prepare for logistic regression analysis, each tree was assigned either 1 (successful) or 0 (unsuccessful) with unsuccessful defined as the mortality of an individual stem by 2004.

Predictors with a $p$-value of 0.05 or less and a variance inflation factor (VIF) of less than 1.99 were selected to evaluate logistic regression model performance based on the chi-square distribution with one degree of freedom. The Hosmer-Lemeshow goodness-of-fit statistic (Hosmer and Lemeshow 1989, p. 140) was used to test the null hypothesis that the equation described the data. For Hosmer-Lemeshow goodness-of-fit $p$-values of 0.05 or less (indicating a poor fit of the equation to our data) the null hypothesis was rejected. It is therefore important to note that predictor $p$-values of 0.05 or less have a different interpretation than the Hosmer-Lemeshow goodness-of-fit $p$-values of 0.05 or less.

\section{Results}

\subsection{Survival Model}

Twelve years after overstory removal to create the openings (fourteen years after initial reproduction measurements), overall survival of white oak advance reproduction was $37 \%$. The greatest 
mortality occurred in seedlings with initial basal stem diameters of less than $1 \mathrm{~cm}$. Survival varied by initial seedling basal diameter, understory treatment, aspect, slope, border tree height and canopy opening diameter. Those relationships are described in the following model:

$$
\begin{gathered}
P_{S}=(1 /(1+\operatorname{EXP}(-(3.576+(0.191 \times \mathrm{dU} 1)+(0.352 \times \mathrm{dU} 2)+(0.00101 \times \text { Aspect })-(0.0245 \\
\times \% \text { Slope })-(0.523 \times 1 / \text { Basal Diameter }(\mathrm{cm}))-(0.121 \times \text { Border Tree Height }(\mathrm{m}))+ \\
(0.00738 \times \text { Canopy Opening Diameter }(\mathrm{m})))))
\end{gathered}
$$

where $P_{S}$ is the probability of survival, dU1 and dU2 are the dummy variables for the competition control treatments as explained in the data analysis and modeling section above, basal diameter is the initial basal diameter in centimeters of the advance reproduction in 1990, border tree height is the average height of trees bordering the opening and canopy opening diameter $(\mathrm{m})$ is the average diameter of the opening area within the drip line of the bordering trees in meters. Dummy variables dU1 and dU2 were coded as 0,0 for understory treatment $U 1$; as 1, 0 for understory treatment U2; and 0,1 for understory treatment U3. The value 3.576 is the constant of the logit model with a $p$-value of $<0.001$.

The Hosmer-Lemeshow goodness-of-fit $p$-value for this model is 0.404 . Predictor $p$-values are as follows: dU1 $=0.035$, dU2 $<0.001$, Aspect $=0.001, \%$ Slope $=0.003,1 /$ Basal Diameter $<0.001$, Border Tree Height $<0.001$ and Canopy Opening Diameter $=0.008$.

\subsection{Competition Control Treatments}

Competition control treatment differences were tested using the Mann-Whitney rank sum test for survival of advance reproduction. For understory treatment 1 (no treatment) vs. understory treatment 2 (mechanical control) there was no statistical difference ( $p$-value $=0.343)$. With that in mind, only survival probabilities for understory treatments U1 (no treatment) and U3 (chemical control) are illustrated. In all cases, the understory control treatment with a herbicide, U3, resulted in higher survival probabilities than for U1-no control of competing vegetation (Figures 1-6).
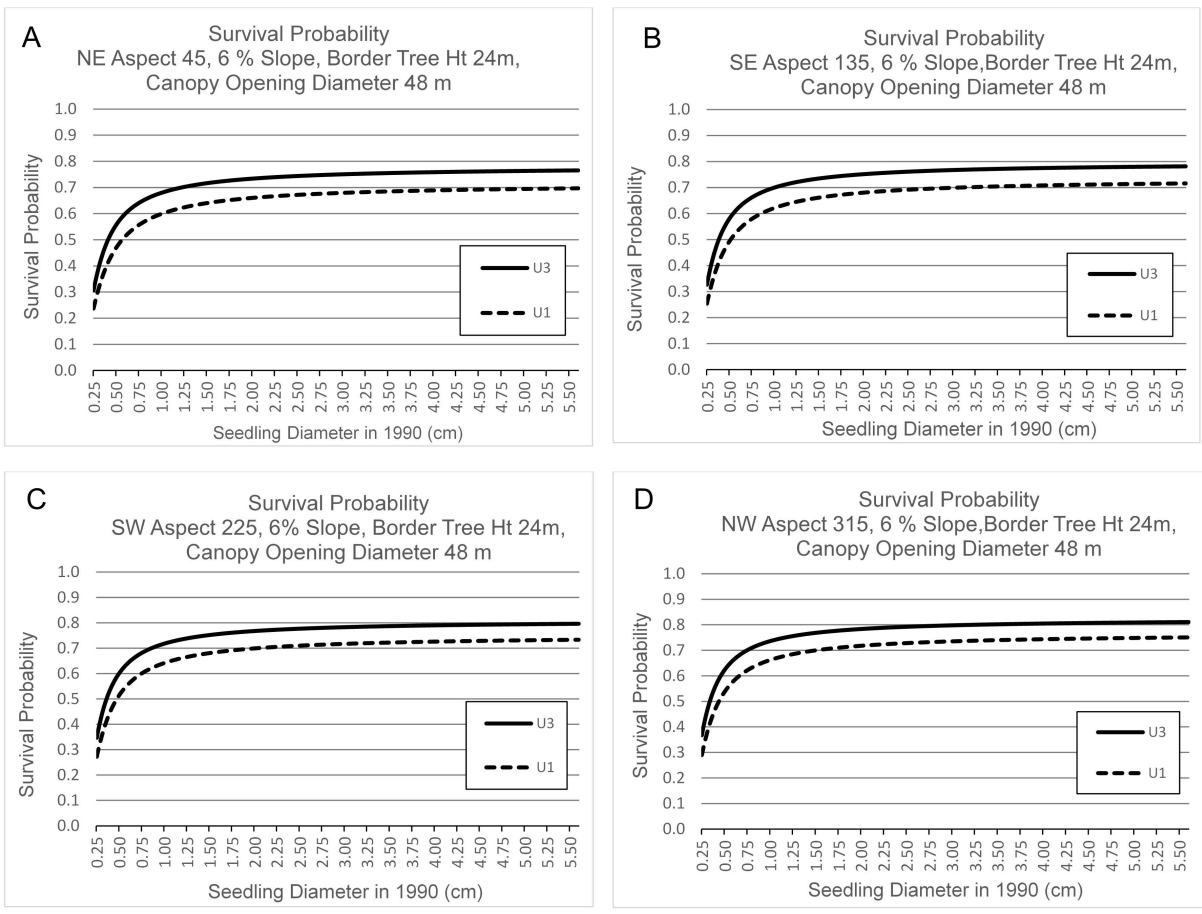

Figure 1. The relationship between seedling diameter, survival probability and understory treatment (U3 is understory treatment with an herbicide applied to cut stems, U1 refers to no understory treatment). (A)-(D) With 6\% slope, canopy border tree height of $24 \mathrm{~m}$, and canopy opening diameter of $48 \mathrm{~m}$. (A) Northeast aspect. (B) Southeast aspect. (C) Southwest aspect. (D) Northwest aspect. 

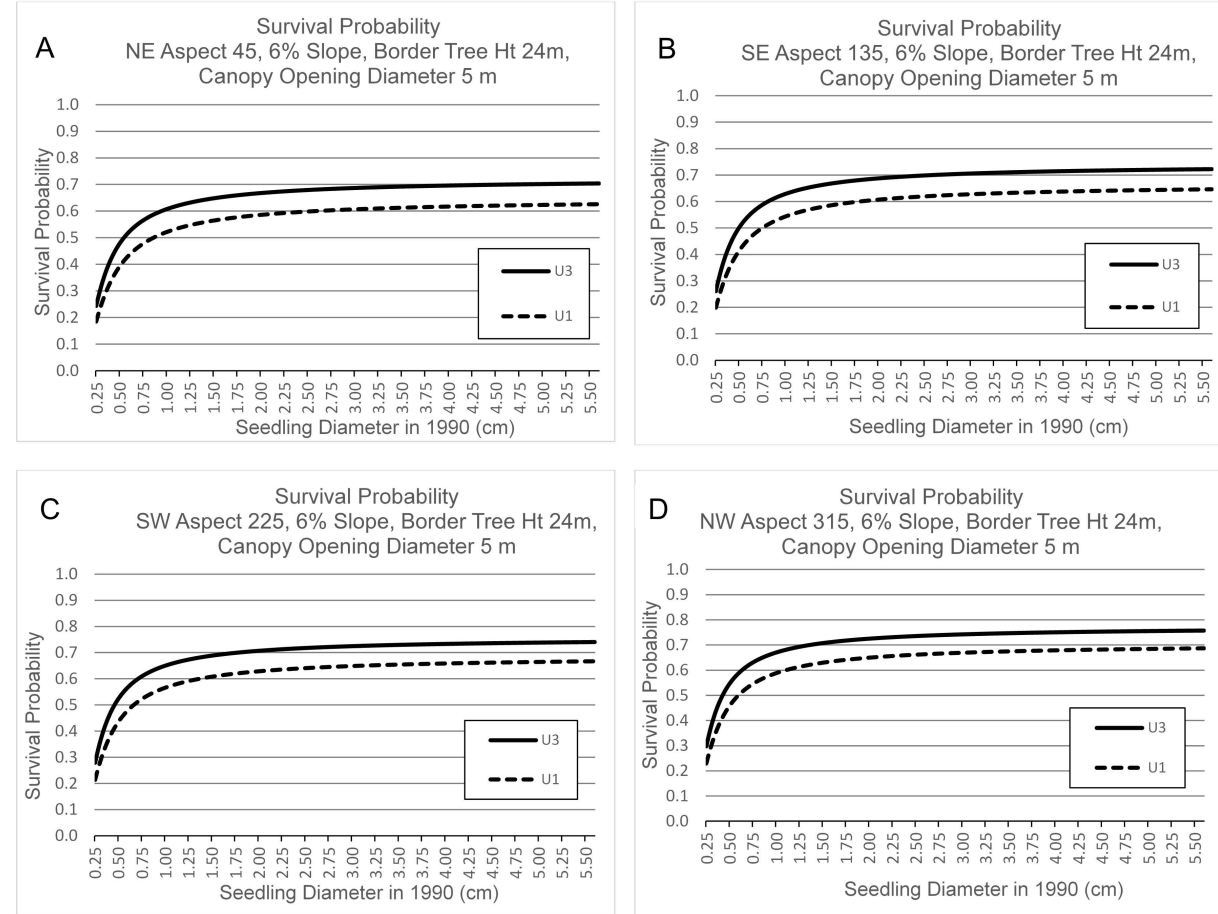

Figure 2. The relationship between seedling diameter, survival probability and understory treatment (U3 is understory treatment with an herbicide applied to cut stems, U1 refers to no understory treatment). (A)-(D) With 6\% slope, canopy border tree height of $24 \mathrm{~m}$, and canopy opening diameter of $5 \mathrm{~m}$. (A) Northeast aspect. (B) Southeast aspect. (C) Southwest aspect. (D) Northwest aspect.
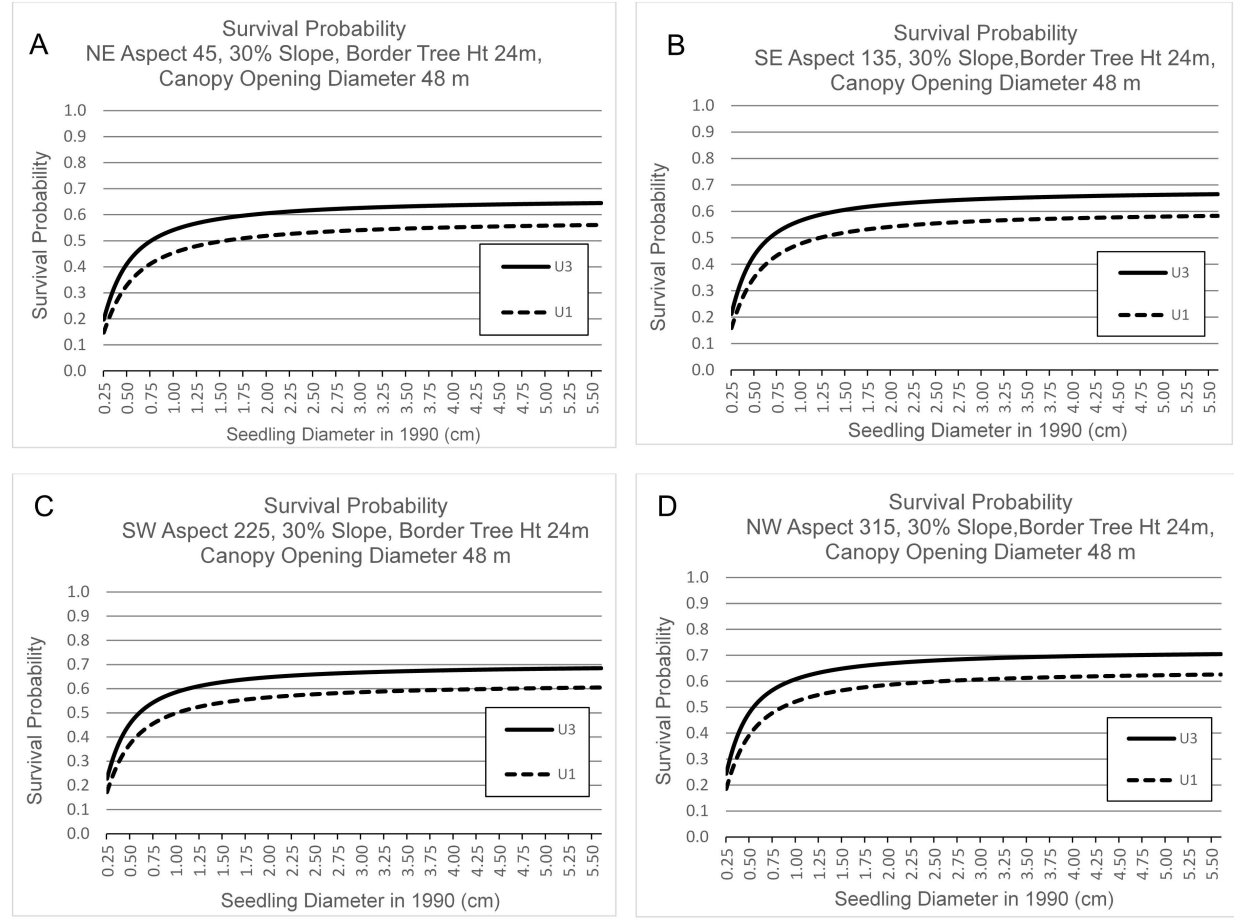

Figure 3. The relationship between seedling diameter, survival probability and understory treatment (U3 is understory treatment with an herbicide applied to cut stems, U1 refers to no understory treatment). (A)-(D) With 30\% slope, canopy border tree height of $24 \mathrm{~m}$, and canopy opening diameter of $48 \mathrm{~m}$. (A) Northeast aspect. (B) Southeast aspect. (C) Southwest aspect. (D) Northwest aspect. 

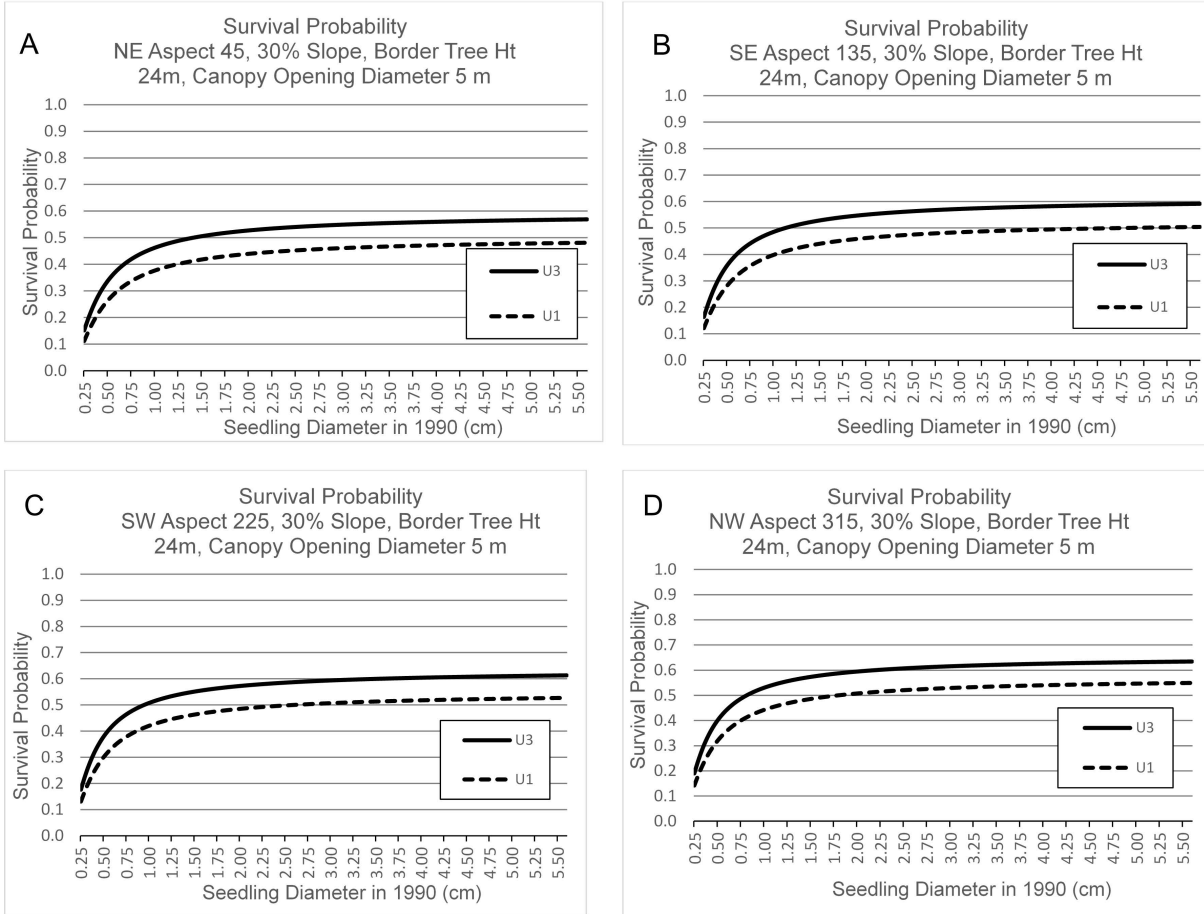

Figure 4. The relationship between seedling diameter, survival probability and understory treatment (U3 is understory treatment with an herbicide applied to cut stems, U1 refers to no understory treatment). (A)-(D) With 30\% slope, canopy border tree height of $24 \mathrm{~m}$, and canopy opening diameter of $5 \mathrm{~m}$. (A) Northeast aspect. (B) Southeast aspect. (C) Southwest aspect. (D) Northwest aspect.
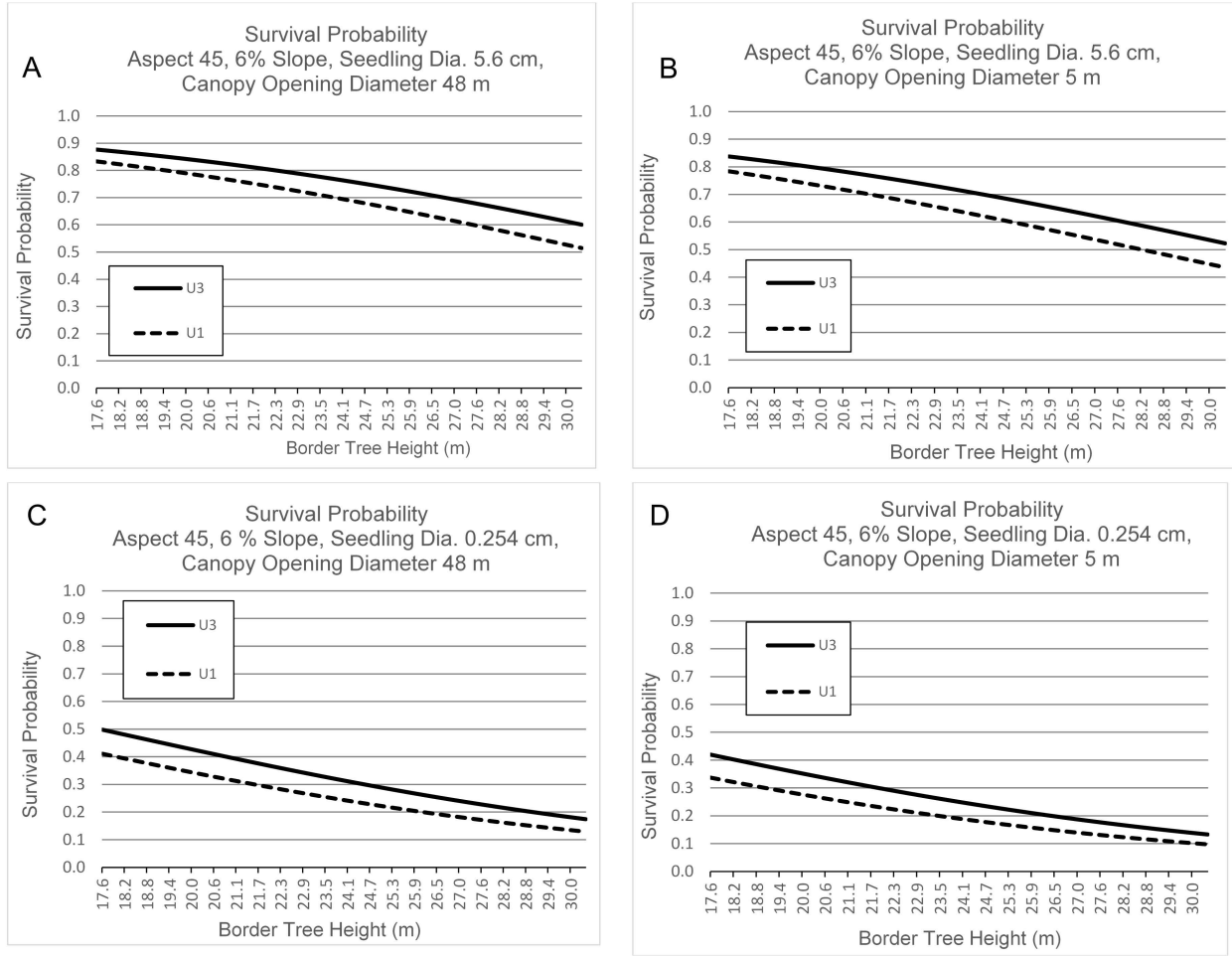

Figure 5. The relationship between canopy border tree height, survival probability and understory treatment (U3 is understory treatment with an herbicide applied to cut stems, U1 refers to no understory treatment). (A)-(D) With aspect of 45 degrees and 6\% slope. (A) Seedling diameter $=5.6 \mathrm{~cm}$, canopy diameter $=48 \mathrm{~m}$. (B) Seedling diameter $=5.6 \mathrm{~cm}$, canopy diameter $=5 \mathrm{~m}$. (C) Seedling diameter $=0.254 \mathrm{~cm}$, canopy opening diameter $=48 \mathrm{~m}$. (D) Seedling diameter $=0.254 \mathrm{~cm}$, canopy opening diameter $=5 \mathrm{~m}$. 

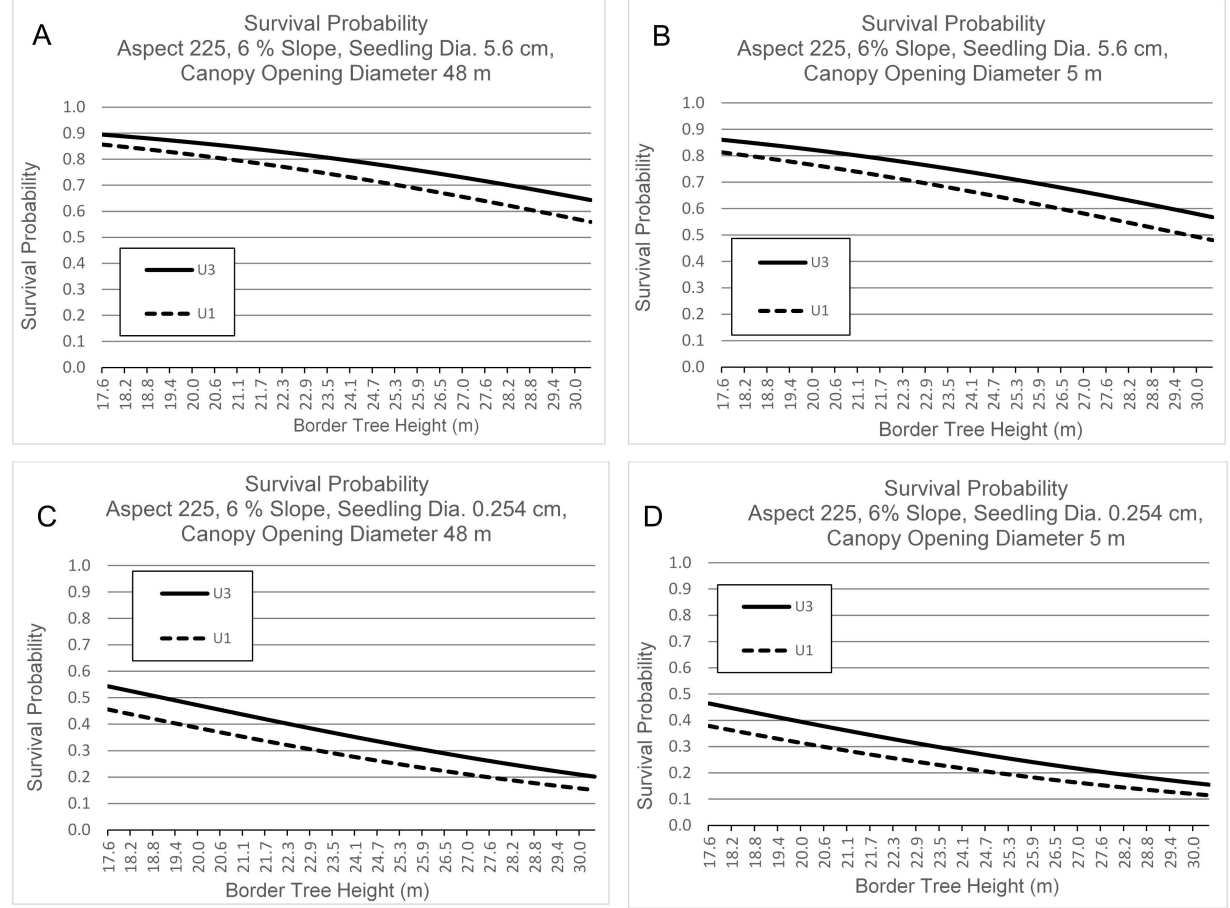

Figure 6. The relationship between canopy border tree height, survival probability and understory treatment (U3 is understory treatment with an herbicide applied to cut stems, U1 refers to no understory treatment). (A) - (D) With aspect of 225 degrees and 6\% slope. (A) Seedling diameter $=5.6 \mathrm{~cm}$, canopy diameter $=48 \mathrm{~m}$. (B) Seedling diameter $=5.6 \mathrm{~cm}$, canopy diameter $=5 \mathrm{~m}$. (C) Seedling diameter $=0.254 \mathrm{~cm}$, canopy opening diameter $=48 \mathrm{~m}$. (D) Seedling diameter $=0.254 \mathrm{~cm}$, canopy opening diameter $=5 \mathrm{~m}$.

\subsection{Survival by Canopy Opening Diameter, Border Tree Height, Seedling Basal Diameter, Aspect and Slope}

White oak survival ranged from $10 \%$ to $90 \%$ (Figure 5D or Figure $6 \mathrm{~A}$ ) and depended on a combination of factors. Survival decreased with increasing border tree height, decreasing seedling diameter and decreasing canopy opening diameter. Additionally, survival was lower at an aspect of 45 degrees than at 225 degrees (Figures 5 and 6).

The greatest survival (90\%) occurred on a 225-degree aspect, initial seedling basal diameter of $5.6 \mathrm{~cm}$, a canopy opening diameter of $48 \mathrm{~m}$ and border tree height of $17.6 \mathrm{~m}$, with competition control (U3) (Figure 6A). Changes in border tree height resulted in relatively large changes in survival probability for all initial advance reproduction diameter classes. Differences in survivability between shortest border tree height and tallest border tree height ranged from 25\% (Figure 6A) to 34\% (Figure 6C).

The lowest survival $(10 \%)$ occurred on a 45 -degree aspect, initial seedling basal diameter of $0.254 \mathrm{~cm}$, a canopy opening diameter of $5 \mathrm{~m}$, no competition control (U1) and border tree height of $30 \mathrm{~m}$ (Figure 5D). For the smallest seedlings with a $0.254 \mathrm{~cm}$ basal diameter, the difference in survival narrowed between understory treatments as border tree height increased in both canopy opening sizes of $48 \mathrm{~m}$ and $5 \mathrm{~m}$ in diameter (Figure $5 \mathrm{C}, \mathrm{D}$ or Figure $6 \mathrm{C}, \mathrm{D}$ ).

From the largest $(48 \mathrm{~m})$ to the smallest $(5 \mathrm{~m})$ canopy openings on $6 \%$ slopes there were relatively small increases in seedling survival as aspect changed from 45 to 135 to 225 to 315 degrees (Figures 1 and 2). Southwest and northwest aspects had somewhat higher survival than northeast and southeast aspects across all initial white oak basal diameters. Increasing slope to $30 \%$ resulted in an overall decrease in survival ranging from $12 \%$ to $14 \%$ for reproduction across initial basal diameters $\geq 1 \mathrm{~cm}$ (Figures 3 and 4 versus Figures 1 and 2). 


\section{Discussion}

\subsection{Competition Control}

Competitors of white oak reproduction in 70 to 90 year old oak-dominated hardwood stands of the Boston Mountains are principally non-oak species and can take up a significant amount of growing space 20 or more years after opening creation. In older stands, these competitors often have limited capacity for height growth or can have relatively high mortality rates in the early stages of stand development. Still, without competition control by fire or other treatment, they are able to continue as advanced reproduction in the understory, influencing survival of oak reproduction for decades [1-4]. This study compared control of white oak competitors to no competition control.

Understory mechanical competition control was no better than no understory treatment in terms of advance reproduction survival. The lack of significant statistical difference between understory treatment U1 (no treatment) vs. understory treatment U2 (mechanical control) is comparable to a similar treatment comparison in an oak underplanting study that also had a no treatment vs. mechanical understory treatment [4]. Although multiple treatments using mechanical control over a period of years may somewhat simulate the top kill effects of repeated prescribed fire treatments, the practice of repeated mechanical control treatments would likely be costly.

While the U3 competition control (chemical control applied to cut stems) consistently resulted in greater survival of white oak reproduction, the maximum increase in survival attributable to this treatment alone was only about $10 \%$. Increasing survival to a greater extent using U3 might be accomplished through follow-up treatments, perhaps at 4 and 8 years after opening creation. However, this would be at increased expense and may be unnecessary if a sufficient number of large advance reproduction trees existed prior to opening creation [20].

Development of a sufficient number of large oak reproduction trees prior to opening creation would likely lead a to greater number of seedlings surviving post-opening creation. Methods to do so include the use of fire or midstory removal. For instance, one study found that fire increased the number of tall oak stems per acre over no fire [21]. Another study found that spring burns and winter burns resulted in increased oak reproduction height 11 years after a single fire in shelterwood stands [22]. Similarly, a study that examined both advance reproduction and underplanted white oak 6 years after midstory removal found greater height and diameter growth due to the midstory treatment [23].

Where herbicide treatment and/or fire is not an option, survival can still be optimized through suitable site and stand selection. For example, in Figure 6A, advance reproduction could reach maximum survival of greater than $80 \%$ without herbicide treatment when border tree height is $20.6 \mathrm{~m}$ or less, canopy opening diameter is $48 \mathrm{~m}$, aspect is 225 , slope is $6 \%$, and advanced reproduction diameter is $5.6 \mathrm{~cm}$ (or greater than $50 \%$ when border tree height is $30 \mathrm{~m}$ or less).

\subsection{Reproduction Size and Survival}

It is well established that oak reproduction increases its probability of survival with increasing basal diameter and that in most stands the number of seedlings per unit area decreases with increasing seedling stem diameter, a negative exponential curve [1]. In studies of oak reproduction survival such as this one, we are often trying to determine the point at which an increase in diameter results in minimal increase in survival. This is the optimal diameter managers need to know, where investing additional effort and resources in seedling development may be inefficient. An underplanting study with understory treatments comparable to those of this study and applied on similar dry-mesic sites in the Ozark National Forest used Northern Red Oak (Quercus rubra L.) with seedling sizes from 0.4 to $2.2 \mathrm{~cm}$ in basal diameter. In that study, survival began to level off at the 1.2-cm basal diameter [4] comparable to $1 \mathrm{~cm}$ in this study of advance natural reproduction. Although there is a difference in species (red vs. white oak), in silvicultural treatment (opening size vs. shelterwood) and in type of reproduction (natural vs. artificial), comparison of the two studies is useful for resource planners 
weighing decisions about silvicultural options, species and potential survival of oak reproduction. When using group selection as a management method, it is advisable to have sufficient advance reproduction of at least $1-\mathrm{cm}$ basal diameter to obtain a high probability of survival after the group opening is created. Similarities in these two studies may indicate that these treatments could be useful for other species and should be considered in the design and implementation of future studies.

\subsection{Canopy Opening Diameter, Border Tree Height, Aspect and Slope}

Changes in canopy opening diameter and aspect resulted in only small changes in survival across all seedling diameter classes (Figures 1 and 2). However, in many cases the largest number of seedlings are in small diameters under $1 \mathrm{~cm}$. Therefore, even a small increase in survival will normally represent more live trees relative to advance reproduction larger than $1 \mathrm{~cm}$. Canopy opening size relates to light availability and may also indicate the degree of root competition. For instance, Longleaf pine studies have indicated that root competition introduced by mature trees can reduce growth of nearby seedlings [24,25].

One aim in utilizing group selection is to minimize the visual impact of harvesting. This study has shown that under the proper combination of conditions, survival of white oak advance reproduction could maintain acceptable survival 12-years after opening creation in even the smallest openings. With the information gained through this study, managers can better match the smallest size of opening to site conditions, treatment and stand conditions.

Boston Mountains and Ozark Highlands forests have been undergoing repeated cycles of oak decline for decades and this is expected to continue into the future [8]. Small openings may be a useful tool in establishment and growth of white oak over other less shade-tolerant but more decline-susceptible species. For instance, red oak is the oak species most suspectable to oak decline while white oak is the most decline-resistant species [6-8]. Additionally, white oak has greater shade tolerance than other oak species such as red oak and black oak (Quercus velutina Lam.); these species would likely respond differently [26,27]. Mitigation of oak decline in the Ozark Highlands will require a shift in species on dry sites where red oak is currently established and highly susceptible to decline [28]. Red oak requires an opening size the diameter of at least one tree height [29] while white oak can achieve acceptable survival in openings of less than one tree height. Utilizing small group openings of less than one tree height could help achieve that species shift by favoring white oak over red oak.

It is unclear from this study if silviculturally altering border tree height would also have a positive impact on reproduction survival, and options to do so would likely be limited. However, based on the relationship between border tree height and survival in this study, it would be reasonable to investigate silviculturally altering border tree height in future studies. Silvicultural control of border tree height through thinning the tallest border trees surrounding the opening may be a viable option to help maximize white oak survival in small group openings. This would produce openings with minimal visual impact by providing a more gradual transition in tree height around the edge of an opening, a feathering effect rather than an abrupt increase in tree height. A study of this type should include site quality measures such as site index to help determine how each factor contributes to advance reproduction survival.

Overall, the optimal combination of conditions for increased survival occurred with the largest advance reproduction diameters, competition control using an herbicide, the largest canopy opening diameters, the shortest border tree heights, minimal slopes, and southwest and northwest aspects. Lowest survival occurred when conditions included the smallest advance reproduction diameters, the smallest canopy opening diameters, no competition control, steep slopes, northeast aspects, and tallest border tree heights.

\section{Conclusions}

The probability of advance reproduction survival was predicted by the level of understory competition control treatment, aspect, slope, initial basal diameter of the advance reproduction, canopy 
opening size and border tree height. Overall survival of advance reproduction in these small group openings was only $37 \%$. However, by utilizing the treatments in this study in combination with optimal site and stand conditions, survival of white oak reproduction can be as high as $90 \%$. Maximizing survival of regenerating white oak in small group openings involved advance reproduction with basal stem diameters of at least $1 \mathrm{~cm}$, minimal slope, southwest or northwest facing slopes, minimal border tree height, larger canopy openings, and competition control using a herbicide. However, if one or more of the factors are not available, for instance if herbicide treatment is not a viable option, then resource managers can choose those sites with the largest number of factors that maximize survival. This knowledge of the probability of success of reproduction after a future harvest based on current site conditions is a valuable tool for forest managers.

Funding: This research received no external funding.

Acknowledgments: I extend my appreciation to Dave Graney (retired SRS scientist) who designed and oversaw installation of this study, to the field technicians who installed and measured this study including Richard Chaney, Jim Whiteside, Arvie Heydenriech, Jesse Swaford, and Kenny King. Thanks to the Ozark National Forest personnel for assistance with stand selection.

Conflicts of Interest: The author declares no conflict of interest.

\section{References}

1. Johnson, P.S.; Shifley, S.R.; Rogers, R.; Dey, D.C.; Kabrick, J.M. The Ecology and Silviculture of Oaks, 3rd ed.; CABI Publishing: Wallingford Oxon, UK, 2019; p. 628.

2. Dey, D.C.; Royo, A.A.; Brose, P.H.; Hutchinson, T.F.; Spetich, M.A.; Stoleson, S.H. An ecologically based approach to oak silviculture: A synthesis of 50 years of oak ecosystem research in North America. Rev. Columbia For. 2010, 13, 201-222.

3. Smith, D.M.; Larson, B.C.; Kelty, M.J.; Ashton, P.M.S. The Practice of Silviculture, Applied Forest Ecology, 9th ed.; John Wiley and Sons: New York, NY, USA, 1997; p. 560. ISBN 0-471-10941-X.

4. Spetich, M.A.; Dey, D.C.; Johnson, P.S.; Graney, D.L. Competitive capacity of Quercus rubra L. planted in Arkansas' Boston Mountains. For. Sci. 2002, 48, 504-517.

5. Lorimer, C.G. The Oak Regeneration Problem: New Evidence on Causes and Possible Solutions (Forest Resource Analyses No. 8, Publ. R3484); Dept. of Forestry, University of Wisconsin-Madison: Madison, WI, USA, 1989; p. 31.

6. Oak, S.W.; Spetich, M.A.; Morin, R.S. Chapter 3: Oak decline in central hardwood forests: Frequency, spatial extent, and scale. In Natural Disturbances and Historic Range of Variation: Type, Frequency, Severity, and Post-Disturbance Structure in Central Hardwood Forests USA; Greenberg, C.H., Collins, B.S., Eds.; Managing Forest Ecosystems; Springer International Publishing: Cham, Switzerland, 2015; Volume 32, p. 400.

7. Spetich, M.A.; Fan, Z.; Sui, Z.; Crosby, M.K.; He, H.S.; Shifley, S.R.; Leininger, T.D.; Moser, W.K. Tree mortality estimates and species distribution probabilities in southeastern United States forests. In Forest Health Monitoring: National Status, Trends, and Analysis 2016; General Technical Report SRS-222; Potter, K.M., Conkling, B.L., Eds.; U.S. Department of Agriculture, Forest Service, Southern Research Station: Asheville, NC, USA, 2017; pp. 175-181. Available online: https://www.srs.fs.fed.us/pubs/54586 (accessed on 25 December 2017).

8. Fan, Z.; Fan, X.; Crosby, M.K.; Moser, W.K.; He, H.S.; Spetich, M.A.; Shifley, S.R. Spatio-temporal trends of oak decline and mortality under periodic regional drought in the Ozark Highlands of Arkansas and Missouri. Forests 2012, 3, 614-631. [CrossRef]

9. Norby, R.J.; Wullschleger, S.D.; Gunderson, C.A.; Nietch, C.T. Increased growth efficiency of Quercus alba trees in a $\mathrm{CO}_{2}$-enriched atmosphere. New Phytol. 1995, 131, 91-97. [CrossRef]

10. Murphy, P.A.; Shelton, M.G.; Graney, D.L. Group selection-problems and possibilities and for the more shade-intolerant species. 9th Cent. Hardwood For. Conf. Gen. Tech. Rep. NC-161 St. Paul MN 1993, 229-247.

11. Fan, Z.; Yao, Q.; Dey, D.; Spetich, M.A.; Ezell, A.; Shifley, S.S.; Kabrick, J.; Jensen, R. Efficacy and associated factors of even- and uneven-aged management to promote oak regeneration in the Missouri Ozarks. For. Sci. 2015, 61, 397-408. [CrossRef] 
12. Jenkins, M.A.; Parker, G.R. Composition and diversity of woody vegetation in silvicultural openings of southern Indiana forests. For. Ecol. Manag. 1998, 109, 57-74. [CrossRef]

13. Wang, W.J.; He, H.S.; Spetich, M.A.; Shifley, S.R.; Thompson, F.R., III; Fraser, J.S. Modeling the effects of harvest alternatives on mitigating oak decline in a Central Hardwood Forest landscape. PLoS ONE 2013, 8, e66713. [CrossRef] [PubMed]

14. Merritt, C. The central region. In Regional Silviculture of the United States, 2nd ed.; Barrett, J.W., Ed.; Wiley: New York, NY, USA, 1980; pp. 107-143.

15. Bailey, R.G.; Avers, P.E.; King, T.; McNab, W.H. Ecoregions and subregions of the United States (map). U.S. Geological Survey, Scale 1:7,5000,000; colored. In Accompanied by a Supplementary Table of Map Unit Descriptions Compiled; McNab, W.H., Bailey, R.G., Eds.; USDA Forest Service: Washington, DC, USA, 1994.

16. Hosmer, D.W.; Lemeshow, S. Applied Logistic Regression; John Wiley and Sons Inc.: New York, NY, USA, 1989; p. 307.

17. Lowell, K.E.; Mitchell, R.J.; Johnson, P.S.; Garrett, H.E.; Cox, G.S. Predicting growth and "Success" of coppice-regenerated oak stems. For. Sci. 1987, 33, 740-749.

18. Johnson, P.S.; Rogers, R. A method for estimating the contribution of planted hardwoods to future stocking. For. Sci. 1985, 3, 883-891.

19. Dey, D.C.; Johnson, P.S.; Garrett, H.E. Modeling the regeneration of oak stands in the Missouri Ozark Highlands. Can. J. For. Res. 1996, 6, 573-583. [CrossRef]

20. Spetich, M.A.; Dey, D.C.; Johnson, P.S. Shelterwood-planted northern red oaks: Integrated costs and options. South J. Appl. For. 2009, 33, 182-186. [CrossRef]

21. Thomas-Van Gundy, M.A.; Wood, K.U.; Rentch, J.S. Impacts of wildfire recency and frequency on an Appalachian oak forest. J. For. 2015, 113, 393-403. [CrossRef]

22. Brose, P.H. Long-term effects of single prescribed fires on hardwood regeneration in oak shelterwood stands. For. Ecol. Manag. 2010, 260, 1516-1524. [CrossRef]

23. Craig, J.M.; Lhotka, J.M.; Stringer, J.W. Response of naturally regenerated and underplanted white oak (Quercus alba L.) seedlings 6-years following midstory removal. In Proceedings of the 18th Central Hardwood Forest Conference, Morgantown, WV, USA, 26-28 March 2012; Miller, G.W., Schuler, T.M., Gottschalk, K.W., Brooks, J.R., Grushecky, S.T., Spong, B.D., Rentch, J.S., Eds.; General Technical Report NRS-P-117; U.S. Department of Agriculture, Forest Service, Northern Research Station: Newtown Square, PA, USA, 2013; pp. 365-372.

24. Brockway, D.G.; Outcalt, K.W. Gap-phase regeneration in longleaf pine wiregrass ecosystems. For. Ecol. Manag. 1998, 106, 125-139. [CrossRef]

25. McGuire, J.P.; Mitchell, R.J.; Moser, E.B.; Picot, S.D.; Gjerstad, D.H.; Hedman, C.W. Gaps in a gappy forest: Plant resources, longleaf pine regeneration, and understory response to tree removal in longleaf pine savannas. Can. J. For. Res. 2001, 31, 765-778. [CrossRef]

26. Wang, W.J.; Thompson, F.R.; He, H.S.; Fraser, J.S.; Dijak, W.D.; Spetich, M.A. Population dynamics has greater effects than climate change on tree species distribution in a temperate forest region. J. Biogeogr. 2018, 45, 2766-2778. [CrossRef]

27. Burns, R.M.; Honkala, B.H. Silvics of North America: 1. Conifers; 2. hardwoods. In Agriculture Handbook 654; USDA Forest Service: Washington, DC, USA, 1990.

28. Spetich, M.A.; Fan, Z.; He, H.S.; Wang, W.J.; Crosby, M.K.; Shifley, S.R. Oak decline across the Ozark Highlands- from stand to landscape and regional scale processes. In Proceedings of the 18th Biennial Southern Silvicultural Research Conference, Knoxville, TN, USA, 2-5 March 2015; General Technical Report SRS-222; U.S. Department of Agriculture, Forest Service, Southern Research Station: Asheville, NC, USA, 2016; p. 641.

29. Fischer, B.C. Designing forest openings for the group selection method. In Proceedings of the First Biennial Southern Silviculture Research Conference, Atlanta, GA, USA, 6-7 November 1980; Barnett, J., Ed.; USDA Forest Service General Technical Report SO-34; USDA Forest Service: Washington, DC, USA, 1981; pp. $274-277$.

(C) 2020 by the author. Licensee MDPI, Basel, Switzerland. This article is an open access article distributed under the terms and conditions of the Creative Commons Attribution (CC BY) license (http://creativecommons.org/licenses/by/4.0/). 